\title{
Politeness of Speech Acts in Indonesian Language By the Native Speaker of Japanese
}

\section{Diana Kartika}

Japanese Literature Department, Faculty of Humanities, Bung Hatta University

\section{Abstract}

This study aims to explain speech act of requesting in Indonesian that has been realized of the native speaker of Japanese by BIPA (bahasa Indonesia untuk Penutur Asing (Indonesian for Foreign Speakers)) students at the University of Indonesia. This research uses qualitative naturalistic methods which means that this research has a natural setting and the researcher is the key instrument. The data collected in this study is noted and recorded, that is the data about the form of requesting in speech acts in Indonesian by Japanese students in classroom interactions, with fellow students or with lecturers. The findings of this study indicate that there are significant changes and

Corresponding Author:

Diana Kartika

dianakartika@bunghatta.ac.id

Received: 18 January 2019

Accepted: 24 March 2019

Published: 31 March 2019

Publishing services provided by Knowledge E

(c) Diana Kartika. This article is distributed under the terms of the Creative Commons.

Attribution License, which permits unrestricted use and redistribution provided that the original author and source are credited.

Selection and Peer-review under the responsibility of the First ELEHIC Conference Committee.

\section{G OPEN ACCESS} the development of strategies used by Japanese students when expressing speech acts invoking Indonesian, both fellow students and lecturers. Nevertheless, these Japanese students did not show a comparable level to changes and developments in the use of internal and external modifications. In addition, there are several forms of violations which are considered as inter-language pragmatic commitments by students when expressing indirect requests. Both in irrelevance in perceiving conformity and irrelevance in the form of speech acts of requesting.

\section{Keywords: Politeness, Speech Act of Requesting, Native Speaker of Japanese}

\section{Introduction}

One of the relevant influences of pragmatic theory on language learning is the importance of politeness aspects in learning a second language or a foreign language. Such learning means learning that pays attention to communicative competencies. Thus stated that the mainstream of language acquisition research concentrates solely on formal linguistics characteristics between languages (Interlanguage) learners are no longer sufficient. Writers as the researcher of the second language acquisition / foreign member gives the close attention to the aspect of pragmatic language learners based on the belief that: (1) a full understanding of the characteristic formal language of the target will not be achieved without researching its use in actual communication, (2) study of language learners require aspects of pragmatics. Thus the purpose of second 
/ foreign language learning research must be able to describe and explain linguistic competencies as well as pragmatic / sociopolitical competencies of students to achieve communicative competence.

Pragmatics competency expressed as the most difficult aspect for students to master in second / foreign language learning. Santoso and Yuvita (2015) argue that: " Learning the language gets implicit knowledge by processing the input language of the target without basis leads to the acquisition of the form and structure of the language. On the other hand, learners get explicit language knowledge when they process language input consciously and find the rules of the language structure ". Whereas Barron (2000) said that "pragmatic failure can occur in interactions between native speakers and non-native speakers, and communication between non-native speakers and non- native speakers, which shows differences in cultural and linguistic backgrounds. This is a common source of misunderstandings and failures in communication. To avoid misunderstandings and failures, learning pragmatics is very important in second language learning. "

The speech act was first put forward by Austin (1962) which was the theory that resulted from his studies and later recorded by J.O. Urmson (1965) with the title How to Do Thing with Words? Requesting in speech acts as part of the directive speech act are chosen as a unit of analysis for four reasons. First, the use and polite realization of the function of directive speech acts become a problem for students in interaction in the classroom because of the lack of opportunities to use directive speech acts in interactions in the classroom. Second, requesting in speech acts involves the realization of speech acts in the form of the use of strategies and also modifications, both internal and external. This is different from other speech acts that do not involve the use of strategies with external modifications. Third, speech acts of requesting as part of directive high-risk speech acts as an act of threatening face, namely speakers suppress the hearers with a risk of losing face to both (Brown and Levinson, 1987: 66) so that strategy selection and speech modification for politeness are the important things. Fourth, speech acts of requesting are often used in everyday communication. In fact, to master this speech act, students must master a number of abilities, namely, interactive skills, knowledge of social rules, and pragmalinguistic knowledge. A speech is not always a direct representation of the meaning of the elements because the emergence of various purposes communicated by speakers in speech act "(Nasution, 2007: 17). Overall the realization of the politeness of speech acts of requesting as part of directive speech acts is likely to be a factor that makes it difficult for students to interact in Indonesian as a foreign language for Japanese students. 
Based on the main problem that has been stated, then the formulation of the problem is: " How does the strategy of speech act of requesting in the Indonesian language carried out by Japanese language speakers on the BIPA Program (Indonesian for Foreign Speakers) both conducted by lecturers and each students of the BIPA Program? The four main points of reference for this research are speech acts, politeness, second language acquisition, and translingual.

\subsection{Speech act}

Actions carried out through speech are called speech acts. Speech acts are the focus of pragmatic studies because all language communication involves speech acts. Austin in Nasution (2007: 16) distinguishes three actions taken by a person when acting in speech, namely acts of locution, illocution and perlocution. Chaer (2004: 16) states that "speech acts are individual symptoms, psychological in nature and their continuity is determined by the speaker's language ability in dealing with certain situations". Requesting in speech acts is part of the directive speech act, which is the action that manifests the effort on the part of the speaker so that the hearer does something to achieve the goal. Practically, there are pragmatic principles related to communication aspects delivered through language that " (1) is not coded by convention generally accepted in linguistics forms used, but it (2) also appears naturally from and depends on the conventionally encoded meanings in the context the place used in these forms "(Rohmadi, 2010).

There are five main groups classification of communicative language functions, called acts of representative, directive, commissive, expressive and declaration. Requesting in speech acts express the desire of the speaker so that the speaker does something with the additional requirement that the wishes expressed by the speaker is the acting reasons for the hearer. Looking more closely at the cost-benefit segment, the requesting in speech act is an illocutionary act whose benefits are available to the speaker and the costs are to the hearer. This action is different from the speech act suggesting, the benefit is in the hearer.

\subsection{Politeness}

There are three core threats in politeness theory, those are "social norms, maxim of conversation and conversation in defending the face ". The theoretical framework of the three politeness theories includes two rationalistic philosophical theories, namely Grice's conversation maxims and Austin's and Searle's speech act theory. Gunarwan (1999) adds 
that "Linguists that have one common view, that basically, in an interaction of people, they do not always adhere to the principle of cooperation Grice". The difference between them lies in the way the experts see the form of unity as a rule (social rules). Every human being takes rational actions to achieve satisfaction of certain desires (wants). The desire associated with the concept of unity is the desire to protect the face. With the ratio, humans try to reach the goal of communication and with their conscious awareness, humans try to fulfill two desires, that is to be respected and not to be forced.

Levinson (1987: 61) suggests that "face is something that is emotionally devoted, can be lost, maintained, or enhanced, and must be constantly considered in interaction." Many speech acts are intrinsically a Face Threatening Acts, hereinafter abbreviated as TP. Selection of the strategy relies on estimates of the seriousness of the pressure, which is assessed on the basis of three factors, those are the power relations between speaker and hearer, the social distance between speaker and hearer, and the absolute pressure of (imposition) a speech in a social context

\subsection{Second language acquisition}

The acquisition of a second language is not intended to be contradicted by obtaining a foreign language. Acquisition without tutors (naturally) and acquisition with tutors (in the classroom) have an opinon conflict between Ellis and Krashen. Ellis uses the terms acquisition and learning as two interchangeable terms. Meanwhile, Krashen argues that acquisition refers to unconscious efforts, while learning is a conscious effort in acquiring language. To explain the acquisition of the second language, there are external factors that influence the acquisition of language, it is social factors and input and interaction factors, while internal factors influenced the process of language acquisition consist of transfer and cognitive elements. Transfer refers to psychological processes. In this process, the previous learning is transferred to a new learning situation. This process creates a difference called positive transfer (facility) and negative transfer (interference). There are two types of interference, those are retroactive barriers and proactive barriers. Retroactive barriers refer to a new learning situations that have a negative impact on previous gains, while proactive barriers refer to the negative influence of the mother tongue of the target language. Based on cognitive elements, Ellis believes the theory of language acquisition is based on assumptions about mastery of language that are gradual. One of the stages that is passed is the inter- language process (Interlanguage) 


\subsection{Translingual}

The term translingual is created by Selingker in 1972 which refers to systematic knowledge of an independent second language (B2). There are fourteen data that show the use of speech acts of requesting when students interact with lecturers. The five strategies used by students are direct application with imperative strategies, especially full imperatives, direct applications with performative strategies, applications that are not directly conventional with strategies to asking the ability of hearers, applications that are not directly conventional with strategies to ask availability, and indirect application by using signaling strategies.

The use of imperative strategies, especially the full imperative, is actually very threatening to the faces of the hearers because as the lecturers, they have more power than students. The similarity between reading strategies for first language readers and second language readers. The reading strategy studied by them were on second language readers by emphasizing interactive reading activities, because readers interact with words to create meaning "(Danasasmita Wawan, 2007: 125). However, the lecturer did not regard this as a serious face threatening act because the lecturer understood the ability of students who were still at BIPA I. When BIPA I students used requesting in speech acts to interact with other students, they used imperative strategies, which were direct applications and strategies asking about ability as part of conventional indirect requests that are oriented towards leadership. The use of speech act strategies carried out by students of Indonesian as a foreign language is closely related to politeness in speaking. Austin (in Rusminto, 2010: 22) first put forward the term speech act. Austin stated that "speaking activities are not only limited to the narrative of something, but also do something on the basis of the utterance ". If looking from Brown and Levinson's politeness theory, the use of imperative strategies is related to using straightforward strategies without further ado/ bluffy (on records without redressive action, baldy). This means that students take verbal actions in the shortest way, broad, direct and as it is. When they use the strategy to eliminate the ability of the hearer, the hearer uses the non-communicative speech in the form of question sentences that begin with the use of able modalities. By fellow friends, the use of the two strategies is considered polite because they realize that they are all just learning Indonesian. 


\section{Method}

The research method used is qualitative naturalistic based on two reasons. First, this research relates to the complex behavior of respondents on how students interact in natural settings and sociopsychological factors that influence their behavior. Second, the object of this research is characterized by interactivity between reality. The effort to interpret interactivity is that researchers must interact with respondents as data sources. Researcher must observes their behavior in a natural setting. The data is responsive to the context. This type of research is in accordance with the paradigm a naturalistic conducted on a natural setting (in the field, open laboratories) that uses natural methods (observation, interviewing, thinking, reading and writing) in natural ways by people who have natural attention to what research they have (practitioners such as teachers, counselors, researchers and evaluators). Specifically there are three approaches used in pragmatic studies between languages, those are cognitive approaches to the development of pragmatics between languages, realization of speech acts and discourse perspectives. This study uses the realization of speech acts.

This research was conducted at the Indonesian Language Program for Foreign Speakers (BIPA), Faculty of Cultural Sciences (FIB), University of Indonesia. Participatory observation was carried out for 3 months. The subjects of this study were Japanese students who studied Indonesian in the BIPA I, II and III Programs, Faculty of Cultural Sciences (FIB), University of Indonesia. The data of this study are the requesting in speech acts in Indonesian that are carried out by Japanese students in the speech interaction events in the BIPA Program classroom. The source of the research data is that 36 Japanese students who study Indonesian language in BIPA I, II and III Programs.

Data collection techniques for speech act research are, observations, questionnaires commonly called tests complementing discourse, and role playing activities. By considering the weakness and the strength per each technic, the research data collection is done through participatory observation that has major advantages. The data collected is the natural conversations data with all the contextual factors. The research data were analyzed and interpreted by reducing data, presenting data, and drawing conclusions. In the data reduction stage, encoding is carried out in levels I, II and III, which means that the speech act is carried out by students of BIPA I, II or III. Data presentation is done based on strategy analysis and modification at each level of BIPA students. To check the validity of the data conducted by diligence of observation, peer checking through discussion, checking by members involved and methodological triangulation by combining observations and interviews. 


\section{Results and Discussion}

\subsection{Results}

\subsubsection{Strategy of speech act requesting with fellow student as the hearer}

In carrying out speech acts of requesting with fellow students, they use four strategies, those are direct requests with imperative strategies, direct requests with strategies expressing obligations or necessities, direct requests with strategies to express desires, and conventional indirect requests. There are only four data found in the situation with fellow students. The small amount of data is caused by the lack of opportunities for students to interact to each other. In addition, even though there is an opportunity to interact, students still tend to be silent. The strategy used when doing speech acts is an imperative strategy, which is part of a direct request and a strategy to ask about ability as part of conventional indirect requests oriented to hearers.

There are three data that using this strategy in conversations conducted by students. This can be seen in the following example.

(a) After Sawa Shimamoto's presentation, a question and answer session was held. Out of curiosity about the contents of the presentation, there were students who asked.

College student: Coba Anda lihatkan lagi lukisan Chagal yang Anda senang. (Maksudnya yang disukai). Maknanya apa? Katanya Anda senang lukisan itu..

Sawa: Eh.... susah ya

Lecturer: Bisa kan Sawa?

Sawa: emh Saya hanya suka saja.

In contrast to the previous example, students softened the speech act to request it using a verb, which can arouse, the impression that speakers do not tell the hearer.

(b) Still in the same context as above when Sawa gave a presentation on the results of his reading. Incidentally, the guides were students from Japan too. When there were no questions at all, the discussion guide was confused. Then, he said

Guide: Tolong teman-teman bertanya, ya. Yang banyak.

Ayo! 
In the previous example the speaker asked friends to ask. Language markers used to soften speech are expressions of help. In addition, speakers use a sign of solidarity and put pressure on a statement, namely the word yes. After that, the speaker closes the speech with the interjection: "Ayo!" to invite and give encouragement.

(c) Context: during an exam in one course, students must play a role in one team. Each team demonstrated their abilities in front of the lecturer, while other friends were outside the class. When the Aki team (student name) wants to go forward, there are friends who come to the class. Aki is embarrassed and doesn't want to be seen by his friends.

Aki: Ketuar! Keluar! Saya malu. (sambil tertawa-tawa).

Friend: Ah, tidak mau. Saya mau lihat (Juga sambil tertawa tawa menggoda Aki).

Aki: Ayo keluar......! (Aki terus meminta temantemannya

keluar sambil tertawa).

\subsubsection{The strategy of speech act of requesting with the lecturer as a hearers}

When conducting a speech act of requesting with a lecturer as a hearer, students use four strategies, namely conventional indirect applications with strategies asking permission or acquisition, indirect applications with strategies to ask for abilities, indirect requests with formula strategy suggestions, and indirect applications with signal strategies. This strategy indirectly taken by the strategy to ask permission. This strategy is mostly chosen by Japanese students when interacting in class. The percentage use of this strategy reaches $57.13 \%$. The speech act of requesting strategy which is not directly the most widely used method is asking for permission. As per example below.

1. Context: In the class, there is a course on scientific writing with bibliographic writing material. BIPA students practice writing biography with various categories, for example the author is one person, the author is more than one person, the author is an institution without a person's name, and so on.

Student: Bu, boleh saya coba yang ketiga?

Lecturer: Mau mencoba? Ya, boleh. Silakan!

College stude: Kalau salah? (sambil tersenyum-senyum)

Lecturer: Kalau salah tidak apa-apa. Nanti kita diskusikan lagi.

(Then the student goes forward and writes his work on the board). 
2. On Monday with the course of Scientific Writing. At that time there was a discussion about the problem of making questionnaires. Each student was asked to make a simple questionnaire.

Student: When Ketika membuat angket, boleh saya minta tolong Ibu?

Lecturer: Boleh saja. Minta tolong apa?

Student: Melihat angket saya. Benar atau salah.

Lecturer: Boleh, boleh. Silakan saja.

Student: Terima kasih.

Lecturer: Sama-sama.

3. On Wednesday. Context: in the ongoing class of Grammar courses, which discusses the use of confixes ke-an in Indonesian.

\section{Student: Pak, boleh saya minta contoh ke-an ditulis?}

Lecturer: Oh, contoh yang kita bahas ditulis dipapan tulis?

Student: Ya, karena saya masih bingung. (Maksudnya

adalah bingung. Sebagian besar mahasiswa

Jepang sulit melafalkan bunyi sengau pada posisi akhir).

4. On Friday. Matta has a Grammar course. The teaching and learning process takes place with the topic of affixes ke-an.

College student: Pak, boleh saya minta contoh ketidakhadiran di depan?

Lecturer: Contoh penggunaannya dalam kalimat, maksudnya?

College student: Ya. Juga contoh yang lain kalau boleh.

Lecturer: Ada yang bisa memberikan contoh? Coba, Ayo siapa bisa?

In all four examples, it appears that the most prominent method used to do this strategy is to use "boleh" as a verbs. The question that was preceded by the phrase may I (boleh saya)... is a question related to the permission of the hearer. These examples show that students can distinguish the epistemic modalities of possibilities with intracausal disclosures dapat, bisa and, boleh even though the distinction is actually not easy because the third differentiator of the modality depends very much on the verbs that follow, whether statif verbs, processes, or actions. 


\subsubsection{Differences in the use of speech act requesting strategy by Japanese students in the BIPA I, II, and III programs}

There were 52 speech acts oof requesting in the conversation fragment analyzed in this research to find out the realization of the requesting speech action strategy conducted by students in BIPA Level I, II, and III Programs at FIB UI. Because the speech acts analyzed are the speech acts in the discourse of classroom interaction in an academic setting, the parameters of persuasion and solidarity are taken into account. Based on that, the data is interpreted as a new level, then each level is grouped into two, namely speech acts carried out by students to students and speech acts that are expressed to the lecturer. The observations on BIPA I received 22 speech acts requesting, which were divided into 4 speech acts of requesting with the student speakers and 18 speech acts with hearers as lecturers. The use of strategies in the two different groups of addressees can be seen in table 3 below.

TABLE 1: The Speech Act Requesting Strategy in BIPA I.

\begin{tabular}{|c|c|c|c|c|}
\hline \multicolumn{3}{|c|}{ STRATEGY } & \multicolumn{2}{|c|}{ SPEAKERS } \\
\hline & & & $\begin{array}{l}\text { Students with } \\
\text { Students }\end{array}$ & Lecturer \\
\hline \multirow[t]{2}{*}{ Category I } & \multicolumn{2}{|c|}{ Indirect Request } & & $14.29 \%$ \\
\hline & Strategy 1: & Signing & & \\
\hline \multirow[t]{3}{*}{ Category II } & \multicolumn{2}{|c|}{$\begin{array}{l}\text { Indirect speech acts Conventionaly hearer } \\
\text { oriented }\end{array}$} & $25 \%$ & $\begin{array}{r}28.57 \% \\
21.43 \%\end{array}$ \\
\hline & Strategy 2: & $\begin{array}{l}\text { Asking ability / willingness } \\
\text { acquisition }\end{array}$ & & \\
\hline & Strategy 3: & Formula advice & & \\
\hline \multirow[t]{3}{*}{ Category III } & \multicolumn{2}{|c|}{$\begin{array}{l}\text { Indirect speech acts Conventionally } \\
\text { speaker oriented }\end{array}$} & & \\
\hline & Strategy 4: & Desire & & \\
\hline & Strategy 5: & Needs & & \\
\hline \multirow[t]{4}{*}{ Category IV } & \multicolumn{2}{|c|}{ Direct Application } & $75 \%$ & $\begin{array}{l}7.14 \% \\
28.57 \%\end{array}$ \\
\hline & Strategy 6: & Obligations & & \\
\hline & Strategy 7: & Performance & & \\
\hline & Strategy 8: & Imperative & & \\
\hline TOTAL & & & 100 & 100 \\
\hline
\end{tabular}

The table above shows that BIPA I students are more likely to use speech acts of requesting directly. However, the observations show that the continuity of speech using 
the imperative strategy was carried out by Japanese students if the hearer was their friend from Japan.

TABLE 2: The Speech Act Requesting Strategy in BIPA II.

\begin{tabular}{|c|c|c|c|c|}
\hline \multicolumn{3}{|c|}{ STRATEGY } & \multicolumn{2}{|c|}{ SPEAKERS } \\
\hline & & & $\begin{array}{l}\text { Students with } \\
\text { Students }\end{array}$ & Lecturer \\
\hline \multirow[t]{2}{*}{ Category I } & \multicolumn{2}{|c|}{ Indirect Request } & $12.5 \%$ & $22.22 \%$ \\
\hline & Strategy $1:$ & Signaling & & \\
\hline \multirow[t]{3}{*}{ Category II } & \multicolumn{2}{|c|}{$\begin{array}{l}\text { Indirect speech acts Conventionally } \\
\text { hearer oriented }\end{array}$} & $25 \% 12.5 \%$ & $\begin{array}{l}33.33 \% \\
22.22 \%\end{array}$ \\
\hline & Strategy 2: & $\begin{array}{l}\text { Asking ability / willingness } \\
\text { acquisition }\end{array}$ & & \\
\hline & Strategy 3: & Formula advice & & \\
\hline \multirow[t]{3}{*}{ Category III } & \multicolumn{2}{|c|}{$\begin{array}{l}\text { Indirect speech acts Conventionally } \\
\text { speaker oriented }\end{array}$} & & \\
\hline & Strategy 4: & Desire & & \\
\hline & Strategy 5: & Needs & & \\
\hline \multirow[t]{4}{*}{ Category IV } & \multicolumn{2}{|c|}{ Direct Application } & $50 \%$ & $22.22 \%$ \\
\hline & Strategy 6: & Obligations & & \\
\hline & Strategy 7: & Performance & & \\
\hline & Strategy 8: & Imperative & & \\
\hline TOTAL & & & 100 & 100 \\
\hline
\end{tabular}

The most striking thing about the use of strategies by BIPA II students above is the use of suggestion formulas. The formula for advice is not used by students to lecturers as hearers and is only taken between the students. This is caused by the assumption that students ask someone else by using formula advice made to people is considered a distance from him. Therefore, even though the suggestion formula was used, the strategy was only applied to fellow students from other countries and had never been used when interacting with fellow students from Japan. The application continues to be used by the students of BIPA II, both to lecturers and to fellow students. However, the strategies used in making requests are directly different. The direct application strategy proposed to lecturers as speakers is more varied and also has a smaller percentage than the direct application submitted to fellow students. The problem is, why do students do speech acts directly asking, whatever the strategy, to lecturers who in the Indonesian context have more power than students? It was answered through data showed that the direct application they made to the lecturer was marked by using a tolong as politeness marker. In their opinion, the use of the word help has helped to show the power of 
politeness though, in the context of Indonesian, the use of the word help does not necessarily soften the speech act and make it polite speech. The observations in the BIPA III class resulted in 11data of speech acts of requesting. Among the data, 6 speech acts carried out by students with their hearers were fellow students and 7 speech acts were carried out to lecturers as hearers. The distribution of the use of each strategy in the two groups of hearers can be seen in table 3 below.

TABLE 3: The Speech Act Requesting Strategy in BIPA III.

\begin{tabular}{|c|c|c|c|c|}
\hline \multicolumn{3}{|c|}{ STRATEGY } & \multicolumn{2}{|c|}{ SPEAKERS } \\
\hline & & & $\begin{array}{l}\text { Students with } \\
\text { students }\end{array}$ & Lecturer \\
\hline \multirow[t]{2}{*}{ Category I } & \multicolumn{2}{|c|}{ Indirect Request } & & $14.29 \%$ \\
\hline & Strategy 1: & Signaling & & \\
\hline \multirow[t]{3}{*}{ Category II } & \multicolumn{2}{|c|}{$\begin{array}{l}\text { Indirect speech acts Conventionally } \\
\text { hearer oriented }\end{array}$} & & $\begin{array}{c}14.29 \% \\
57.13 \% \\
14.29 \%\end{array}$ \\
\hline & Strategy 2: & $\begin{array}{l}\text { Asking K Capacity of will/ } \\
\text { acquisition }\end{array}$ & & \\
\hline & Strategy 3: & Formula advice & & \\
\hline \multirow[t]{3}{*}{ Category III } & \multicolumn{2}{|c|}{$\begin{array}{l}\text { Indirect speech acts Conventionally } \\
\text { speaker oriented }\end{array}$} & $16.67 \%$ & \\
\hline & Strategy 4: & Desire & & \\
\hline & Strategy 5: & Needs & & \\
\hline \multirow[t]{4}{*}{ Category IV } & \multicolumn{2}{|c|}{ Direct Application } & $\begin{array}{l}16.67 \% \\
66.66 \%\end{array}$ & \\
\hline & Strategy 6: & Obligations & & \\
\hline & Strategy 7: & Performance & & \\
\hline & Strategy 8: & Imperative & & \\
\hline TOTAL & & & 100 & 100 \\
\hline
\end{tabular}

There are differences in the use of strategies that are very striking by BIPA III students compared to students in BIPA I and BIPA II. BIPA III students as a whole use indirect application strategies to lecturers. Meanwhile, BIPA I and II students still use direct applications with various strategies when interacting with lecturers as speakers. The opposite also happened, namely a drastic increase (83.34\%) using direct applications with various strategies carried out by students to fellow students as hearers. Based on student recognition, togetherness during the course of the study brought them closer psychologically. Because of this, social distance between students is increasingly receding. This caused their courage to use indirect speech acts because they assumed that the speech act would not "eliminate the face" of their friends as hearers. The imperative form which is 
part of the act of direct request is most often chosen by students in committing acts, both to the lecturers and their own friends as hearers. It is actually very surprising, since for native speakers of Indonesian as the imperative mode of requesting strategy, it commonly used by speakers who have a higher status than the hearers or an urgent factors may override considerations of the face. The imperative form is used by students at the beginning of their entry into the BIPA Program. In addition, the form is also most often found in two situations, that are asking the lecturer to examine the assignment when the student is doing the assignment, the class assignment and the situation when the student asks the lecturer to write down quite huge letter size because it is not too visible from the back of the class.

To fellow students from Japan, they prefer to use the imperative strategy even though it is done in formal situations in the classroom. It actually feels strange because the formal situation in the classroom does not always require the use of the imperative mode, especially with fellow friends. However, this can still be understood if solidarity factors are considered to assess the speech politeness they make. Based on the results of interviews, the imperative mode they thought would not harm the face of the hearers because of the solidarity factor between them. After all, they always say it using humor.

\section{Discussion}

Regarding the selection of the continuity level of speech, the choice of strategy at the three levels of students shows the change from the direct speech action to the indirect speech act when they interact with the lecturer as a hearer. BIPA I students tend to use direct speech acts even if they are done to the lecturer. Inevitably there is a change in BIPA II students who begin to use the speech not directly even though it is not yet dominant in their choice of strategy. Drastic changes occurred in the dominant BIPA III students using indirect speech acts. Especially for lecturers as hearers. Lack of indirect strategy. Especially the signaling strategy, in the BIPA I and BIPA II student groups showed a lack of use of softness, which was emphasized by the very minimal use of modifications in speech action strategies of requesting for them. Although in the end students use indirect speech act strategies for lecturers, the indirect strategy they use is not a signaling strategy, but a conventional direct oriented speech act strategy, namely a strategy to reduce ability / willingness / acquisition. The gesture strategy is the strategy for direct action requests that are at least selected. That is what is explained from the perspective of second language acquisition of politeness and theory. The signaling strategy was questioned in this section because Indonesian people in carrying out speech 
acts requesting used it to ask many signaling strategies. Cues are related to the ethos of unsustainability and are widely used by Indonesian speakers from Javanese ethnic groups.

This research data shows that Japanese students use very few signaling strategies when doing the speech acts of requesting. Signaling strategies are increasingly used when students are already in the BIPA III program, which means the emergence use of signaling strategies in this research is relatively the latest compared to the use of other strategies. This can be explained based on several previous research findings, both relating to the acquisition in the first language and in the second language. The signaling strategies discussed in this study can be compared with the utterances made by children when they get the first language.

Most of the speech acts of requesting in BIPA I, II and III students also use the speech act of requesting indirectly strategy through questions, especially when interacting with lecturers. Questions are more polite when used to perform speech acts for hearers and the option to do a rejection of acts of the desired speaker through speech acts. Unfortunately, Japanese students' speech acts with this strategy are not as natural as Indonesian speakers because almost all strategies of all requesting of speech act by using the questions made are positive questions. In fact, Indonesian speakers often make speech acts of requesting with negative politeness strategies.

Not using the strategy of using questions with negators by Japanese students is a problem that must be explained because basically in Japanese there are also known positive and negative questions. This is different from English, for example, which considers positive questions more polite than negative questions. In Indonesian, some informants stated that positive questions are more polite than negative ones. This difference in perception seems to make Japanese students take the decision to use positive questions in Indonesian even though in certain circumstances Indonesian native speakers also use negative questions when performing invoking speech acts.

Difficulties in the selection of strategies by Japanese students when using Indonesian are very likely to occur due to differences in politeness systems in Indonesian and in Japanese. Courtesy in Indonesian is very much influenced by strategy when acting speech by considering aspects of power, solidarity, and the level of pressure caused by speech acts. In Indonesian, politeness does not involve a form of honorific that influences morphological and syntactic processes. Politeness in the use of the Japanese language called wakimae is a choice of languages that are "automatic" and " mandatory "sociopathic aspect as well as aspects of grammar, is a choice of profit that 
must be made when making speeches. It was interpreted that in Japanese, the concept of politeness was put in place as a social reference. Wakimae is a sociopragmatic harmony, that is, the behavior of a person's politeness dictated by his social position and social relations with the hearers. Verbal behavior effectively functions as a social reference mechanism. Even in non-threatening facial expressions, speakers are "forced" to make choices between various available variants, with or without honorifics according to background formalities and inter-participant relationships.

The type of politeness that allows active speakers to choose strategies when interacting is called volition(willing) which is contradicted with discernment, which in Japanese is called wakimae. Wakimae is not a will because it does not depend on the freedom of the speaker, but is a choice (grammatical form) that is socially obligatory. Acting according to Wakimae means showing the meaning of place or someone's role verbally (and nonverbally) in certain situations according to social conventions. The difference between discourse or wakimae with volition can be explained as follows. Discerment is realized mainly through various forms of formal linguistics, which are compulsory choices, which implicitly message about speakers' understanding of social situations. It involves various formal forms such as honorifics,pronouns, greeting forms, tutu levels, speech formulas and so on. Meanwhile, volition is done by selecting verbal strategies, such as seeking humorous approval, showing pessimism, minimizing pressure, and so on.

Indonesian speakers generally use internal modification in performing requesting speech acts. According to Hassall (2001: 262-266), the most common internal modification used by Indonesian speakers is the negator, which consists of tidak, enggak, and ndak. The last two negators are used in informal situations. Furthermore, Indonesian language speakers use other modifications, namely the form of greetings, statements to minimize impotition such as brief words and sebentar saja, sedikit saja, namely the word $y a$. Indonesian native speakers often exploit internal modification devices by combining different types of modified devices in one speech.

Data on the use of internal modification in appealing speech acts by Japanese students shows that of the many devices that can be used to soften the speech, only modifying internally is syntactic softening with the questions and insertions used. Another way is like affirmation, tag question, conditional clauses, are not used. The internal modification in the form of a lexical softener that is most often used is a marker of tolong. Meanwhile, the shield device (shield) as the word mungkin, barangkali; the fence device approximator as said kira-kira; downsizing expression (understatement) 
like sebentar saja, sedikit saja; fence devices are expressions of doubt as saya kira, menurut kami, saya rasa, saya pikir, sepertinya; they have never been used.

Thus, it can be stated that Japanese students in the BIPA Program use different internal modifications to Indonesian speakers. Japanese students use very little internal modification and do not use the type of internal modification most commonly used by Indonesian speakers. This lack use of internal modification by Japanese students is consistent with several previous studies. Foreign students, both at the elementary, intermediate, or advanced, using an internal modification in the speech act far less than native speakers.

This raises two questions. First, does the use of internal modification in the speech act of requesting by the Japanese student reduce the level of politeness or even be considered polite? As a whole it can be said that their speech certainly becomes very visible that it is the speech of non-native Indonesian speakers even though Indonesian native speakers will not be able to show which situation requires the use of internal modification and the situation which does not require the use of internal modifications. Even so, the limited mastery of internal modifications of Japanese students in the BIPA Program greatly limits the choice of strategies in making speech acts of requesting. That is, repeator the internal modification that students have is very few.

Second, why Japanese students using far less than the internal modifications of Indonesian native speakers in general? Japanese students find it difficult to modify speech acts of requesting because the absence of the Indonesian language system that constantly used to show politeness, both in terms of word choice, honorific usage, and morphological and syntactic changes. This is very different from the Japanese language system which expressly divides the level (crooked steps) of their language into two levels, namely polite speech and familiar speech. According to Ozamu Mizutani and Nobuko Mizutani (1987: 59-78), polite speech is used in social situations such as conversations between acquaintances and strangers, while familiar utterances are used in intimate conversations between good friends, family. The difference in the two levels of language appears at the end of the sentence and the choice of vocabulary. In Japanese, polite speech usually ends in polite form, namely desu and masu, while intimate utterances end with ordinary forms, namely the form of adjectives and verbs as in the dictionary and in the form of $d a$.

The difference in the form of courtesy (polite form ) and ordinary (plain form ) in Japanese can be seen in the use of verbs, adjectives, pseudo adjectives (quasiadjectives), nouns, and other differences such as the use of particles. For this reason, 
Japanese speakers in realizing verbal politeness do not depend on choosing internal modifications such as Indonesian. With the selection of the various forms above, Japanese speakers can express their politeness, this difference makes it difficult for Japanese students when they have to modify the requesting speech acts in Indonesian. In addition to the differences in the language system, the causes of Japanese students' use of internal modification in speech acts are the addition of internal modifications in speech makes speech more complicated.

In addition, it is difficult for students to use internal modification in requesting speech acts due to the frequent use of the word help in their daily interactions with Indonesian native speakers. Students feel that by using the word tolong, their speech will be polite to anyone. In fact, in everyday life Indonesian speakers are not like that. Using a word tolong still be accompanied by other internal modifications and also a strategy that is deemed to be in accordance with the speech situation to maintain politeness by considering the hearer, level of solidarity, and level of pressure. Meanwhile, the limitations of vocabulary make it possible for them to know that only a few softwares, including hedges . Based on the results of the interviews, towards the end of the lecture they actually knew some words / phrases that could actually be a fence in acting to requesting as mungkin, barangkali, menurut saya, and saya pikir. They thought that the word / phrase could only be used to express representative speech acts.

Japanese students only use one external modification, the supporting reason. For example, when they ask the lecturer to enlarge his writing, the student gives the reason that he cannot read it. Other external modification devices are not used at all like preparators which consist of preparing contents, preparing speech acts, checking availability, and looking for precommitments; empowerers, sweeteners, minimizing costs, and promising rewards also did not appear in their words. Due to the use of supporting reasons as the main external modification device, it can be explained based on the findings of previous research.

BIPA I students have used external modification in the form of supporting reasons when carrying out speech acts of requesting even though they are still less in pragmalinguistic. This can be explained in terms of the explicitness of proportional meaning. Supporting reasons as part of external modification express the proportional meaning of speech explicitly and students consciously use it. There are two reasons why students consciously use supporting reasons in this speech acts of requesting. First, according to Blum-Kulka and Olshtain (1986: 171), students really want to use the supporting reasons in the speech acts of requesting because they have a lack of confidence in terms of their ability to make the intention of the speech act to be understood by the hearers. 
Second, probably also because the lack of their confidence in their ability to make their speech polite.

Supposedly, for the use of this external modification, Japanese students do not experience difficulties because according to Osamu Mizutani and Nobuko Mizutani (1987: 108-110), Japanese speakers when carrying out speech acts must express their regret for disturbing others by using no expressions direct and the end of the appropriate sentence. There are some expressions of remorse for disturbing others, namely summimasen-ga (saya minta maaf, tetapi...), oisogashii tokoro-o (ketika Anda sibuk), gomeewaku-towa omoimasu-ga (Saya tahu ini menyusahkan Anda, tetapi...). It can be interpreted that in Japanese politeness, Japanese speakers can use external modifications to soften the requesting in speech acts.

A form of politeness in language learning in the BIPA program based on research findings is the issue and discussion of this study reminds the curriculum compilers and instructors about the importance of inputting politeness aspects in the BIPA learning process. Politeness as part of the discussion of pragmatics so far has received a very small portion because it is still considered difficult to teach it. Meanwhile, grammar is a learning material that traditionally gets the largest portion of language learning. Thomas (1983: 97) gives two reasons for this. First, the description of pragmatics cannot be as precise as the description of grammar in explaining the linguistic competencies needed by the learner. Second, pragmatics is a "gray" area so there is no clarity on how to teach pragmatics. Although pragmatics is a "gray area", perhaps we still agree that politeness as one of the pragmatic fields should be taught to BIPA students because "there is no face-toface communication. Therefore, BIPA students must be made aware of the importance of the choice words made by participants in producing and interpreting messages under certain sociocognitive constraints to increase sociopragmatic awareness in producing and understanding speech. Awareness raising will also increase other awareness, it is about differences and similarities in expressions of language based on social relations across genres and across cultures.

That way, the efficient foreign language learning must take place within the framework of a pragmatic perspective, it is not learning by the practice of phonetic / phonological and morphosyntactic presentation. Learning with such linguistic models must be contextualized and related to the situation used to familiarize students with the sociology of interlocutor relations in Indonesian. BIPA students will be considered successful in communicating in Indonesian if they are able to convey their message in Indonesian using appropriate structures in the context use. If the opinion is approved, learning in the BIPA program must be enacted from a pragmatic point, one of which goes from the 
theory of politeness. Politeness theory actually offers adequate tools to teach forms of language in context. Thus, students of the BIPA program are not only able to express the proportional content of their messages, but are also able to create messages according to the needs of social interactions because failure to find social parameters that can lead to pragmatic failure or even communication failure.

Politeness theory offers devices that are good for students to learn making the form of choices and strategy determined by the sociocognitive and cultural constraints of a situation. Even so, there are also some who doubt that. If there are pragmatic failures like those made by Japanese students in the selection of strategies and the use of modifications, both external and internal, there are at least three activities that can be done to understand the causes. First, lecturers and students can discuss appropriateness in the context of both cultures, namely Indonesian culture. Second, as much as possible the lecturer avoids prescriptivism and tries to use the results of student observations, then discusses and compares dialogue in communication that is considered successful and unsuccessful to improve understanding of linguistic behavior. Third, lecturers can modify the textbook dialogue and make students participate in the role play to increase student awareness about the social and cultural factors that determine pragmalinguistic elections. These activities are designed to enhance positive attitudes towards cultural differences and their influence on how to realize politeness with the aim of reducing cultural stereotyping.

Reflecting on the findings of this study, it can be stated that the choice of strategy in speech act to achieve politeness is an aspect that needs to be considered in BIPA learning. Students must increase their awareness about acting strategies to realize politeness and the choice of various forms of language in building social interaction. The methodological steps that can be taken can is stated below. First, students are introduced to the description of lexicocystaxis and the prosodic realization of linguistic politeness. Second, students are introduced to courtesy systems: respect, solidarity and hierarchy associated with Brown's sociocultural aspects.

\section{Conclusion}

First, the use of speech act strategies of requesting in Indonesian. When BIPA I students doing speech acts of requesting with the lecturers to use a score that is much more varied compared to when they are reacted with fellow students. The use of speech act requesting strategy by Japanese student at BIPA II, both to fellow students and professors, distributed evenly in almost all categories of strategy, that imperatives strategy, 
direct categorize strategy, the strategy of asking the ability / willingness / acquisition (conventional speech oriented category of indirect speech) and signaling strategies (the most indirect application category). While BIPA III students through the dominant choice of strategies are categorized as direct requests, especially the imperative strategy and declaring obligations (the most direct category of application categories). The use of the strategy expresses the desires of speakers are very few, which are categorized as conventional speech act in speaker oriented. Meanwhile, understanding the difference role between students and lecturers as well as increasing language skills, led to the dominant use of indirect category strategies when students interacted with lecturers as hearers. The strategy that they use is asking strategy for ability / willingness / acquisition, formula suggestions and signaling strategies.

Second, differences in strategy use by BIPA I, II and III students. The higher their level of ability, the more the students reduce the speech action strategy directly, especially the imperative and performative strategies and show little change in signaling strategies, especially when interacting with lecturers. At the same time, students increased the use of conventional indirect speech acts, which almost matched with Indonesian speakers when they interacted with lecturers as hearers. The findings of the strategies used by students of BIPA I, II and III indicate that conventional indirect strategies are the dominant strategies used by students in this study.

Third, the use of modifications in speech acts of requesting. In terms of the use of internal modification, Japanese students use a very little internal modification and they do not use the type of internal modification which most commonly used by Indonesian speakers, that is negator. There are two syntactic devices that are used by BIPA I students to modify speech acts to ask them to speak. By using questions and insertions. Students also use politeness markers as part of phrasal / lexical downgraders. Meanwhile, the research data does not indicate the use of external modification by BIPA I. students of BIPA II use two internal modification devices, namely (1) syntactic downgraders in the form of conditional clauses and questions,(2) phrasal devices / lexical downgraders in the form of the use of words please, excuse me, sorry and try to start the speech. The external modification used by BIPA II students was the use of supporting reasons, which were placed at the beginning and end of the speech. BIPA III students use two internal modification devices, namely (1) syntactic downgraders in the form of questions and conditional clauses, (2) pharasal / lexical downgraders in the form of markers of politeness and markers of interpersonal. The research data does not indicate the use of external modification by BIPA III students. 
Fourth, the use of modified speech acts iof requesting by students BIPA I, II and III. In terms of the use of internal modification, students at three levels tend to use syntactic downgraders in the form of questions and conditional clauses and the use of phrasal / lexical downgraders in the form of politeness markers. This happens because the use of internal modification makes speech act more complicated so it requires extra hard effort on students to produce their speech. In this case the use of external modification by students only use the supporting reasons. Students do not use other external modification devices. This happens because of supporting reasons it is an external modification tool for requesting the speech acts that apply across languages so that students only need to transfer pragmatic knowledge from first language into Indonesian.

Fifth, cases of non- continuity of speech in pragmatics between languages. There are deviations made by students in the use of indirect speech, those are deviations in perceiving politeness and deviations in the form used. The continuity of other speeches seemed to be depart that is the use of conventional direct speech act.

\section{References}

[1] Austin, JL 1962. How to Do Things with Words. London: Oxford University Press

[2] Blum-Kulka, S. 1984. 'Interpreting and performing speech acts in a second language: a cross-cultural study of Hebrew and English' in N. Wolfson and J. Elliot (eds.). TESOL and Sociolinguistic Research. Rowley, MA: Newbury House.

[3] Chaer A. and Agustina L. 2010. Sociolinguistics Early Introduction . Jakarta: Rineka Cipta.

[4] Danasasmita Wawan, 2007. Effectiveness of the Directed Reading Act (DRA) Model in Teaching Reading Indonesian as a Foreign Language . Educationist Vol Journal. I No. 2 / July 2007

[5] Ellis, Rod. 1985. Understanding Second Language Acquisition . Oxford: Oxford University Press.

[6] Hassall, Tim. 1999. Request Strategies in Indonesian, Pragmatiks, Vol. 9 No. 4. Kasper, Gabriele and Shoshana Blum Kulka. 1993. Interlanguange Pragmatiks : An Introduction. Newyork: Oxford University Press.

[7] Levinson and Soekanto, 2009. Role, New Edition of Rajawali Press, Jakarta.

[8] Mizutani, Osamu and Nobuko Mizutani. 1987. How To Be Polite In Japanese . Tokyo: The Japan Times.

[9] Nasution Khairina. 2007. Speech Acts and Speech Acts in andailing M Language . Article: History. Issue No. 23 / Year XI / January 2007. 
[10] Rohmadi, Muhammad. 20 10. Pragmatic Theory and Analysis . Yogyakarta: Jogja Media Circle.

[11] Rusminto, NE 2010. Understanding Children's Language. Bandar Lampung: University of Lampung.

[12] Thomas, Jenny. 1983. Cross-Cultural Pragmatics Failure , Applied Linguistics, Vol. 4 No. 2. pp. 91-112. 